\title{
IR SPECTROSCOPIC CHARACTERS OF GARNETS AND SPINELS - A POTENTIAL DISCRIMINATIVE TOOL FOR DIAMOND EXPLORATION.
}

\author{
Lihe Guo; Wuyi Wang;Alian Wang and Andi Zhang.
}

Institute of Mineral Deposits, CAGS, Beijing 100037, China.

Garnet and chromite are two important indicator minerals for diamond exploration. Most reported studies were focused on their compositional characters $[1,2,3,4,5,6,7,8]$ over the years. Although the structural refinement analysis $[9,10,11]$, and spectroscopic studies $[12,13,14]$ of garnet and spinel have been done in detail, but there is no one using the structural characters of garnet and chromite to discriminate primary diamond sources so far.

In recent years, the structure and spectroscopic features of above two mincrals have been studied by the authors [15,16,17 for garnet and 18,19 for chromite]. It has been discovered that there are some peculiar garncts and chromites to diamondiferous kimberlitic rocks. An IR microanalysis method has bcen established [18]. In order to contrast the spectroscopic character with its chemical composition of these two minerals because the IR spectroscopic and compositional information could be obtained from the same grain.
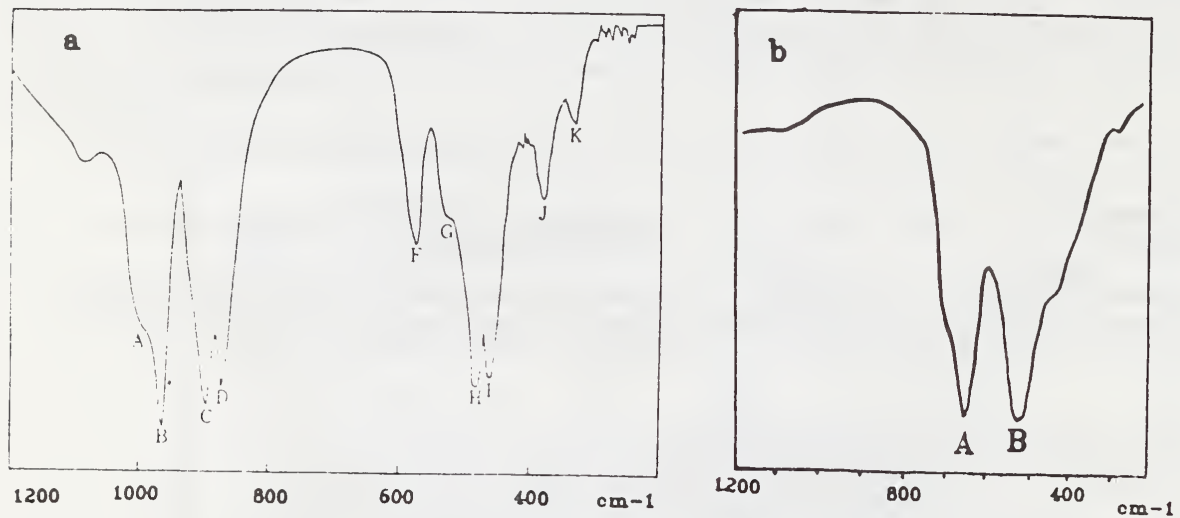

Fig. 1 IR spectra of $G$ arnet(a) and chromite(b)

Figure 1 a is a typical IR spectrum of garnet. The frequency differences of band positions $\left(v_{\mathrm{C}}-v_{\mathrm{D}}\right)$ and $v_{B}-\left(v_{C}+v_{v}\right) / 2$ are assigned factor group splitting and site group splitting respectively. These t $v_{i}$ ? spectral characters are concerned with the substitution of ions $\mathrm{Al}^{3+}, \mathrm{Cr}^{3+}$ and $\mathrm{Fe}^{3+}$ in octahedron, ar . $\mathrm{Ng}^{2+}, \mathrm{Fe}^{2+}$ and $\mathrm{Ca}^{2+}$ in dodecahedron. The $\mathrm{X}-\mathrm{Y}$ diagram drawn by using factor group splitting (ordinate) and site group splitting (abscissa) shows that more than $15 \%$ garnets of each diamondifero $x$. kimberlite body with site group splitting larger than $85 \mathrm{~cm}^{-1}$ because they have subcalcium ir dodecahedron and smaller factor group splitting because of their rich chromium contents in octahedron (Fig. 2a-d). However, in all non-diamondiferous rocks, there are no garnet with the above characters (Fig. 2e-h).

IR spectra of most chromites show two strong bands (Fig. 1b). The shift of high-frequency band $A$ is concerned with the distortion of octahedron which is mainly caused by the substitution of $\mathrm{Al}^{3+}, \mathrm{Cr}^{3+}$ and $\mathrm{Fe}^{3+}$. Another $\mathrm{X}-\mathrm{Y}$ diagram drawn by using the positions of band $\mathrm{A}$ (abscissa) and band $\mathrm{B}$ (ordinate) shows that most chromites from diamondiferous kimberlitic rocks are located at the range of $635-625 \mathrm{~cm}^{-1}$ for band $\mathrm{A}$, and $505-495 \mathrm{~cm}^{-1}$ for band $\mathrm{B}$ (Fig. $3 \mathrm{a}-\mathrm{c}, \mathrm{h}$ ), but those from barren rocks are normally located out of this range (Fig. 3d,e-g).

Part of this work is supported by the Department of Geology, U.W.A. and CRA Fxploration Pty l.imited. Many thanks to Prof. P.G. Harris, Dr. W.J.Chang, Prof. N.M.S. Rock and Dr. C.Smith. 
References:

(1) Sobolcv N.V. ct al, 1973, Contrib. Mincral. Pctrol., 31, 1-12

(2) Dawson J.B. and Stephens W.E., 1975, J. Gcol., 83, 589-607

(3) Gurncy J.J., 1984, Univ.W.A. Pulb. 8, 134-166

(4) Gurncy J.J. and Moorc R.O., 1989, In: The Report of Can. Gcol. Surv. The Devolopment of Advanced Technology to Distinguish between Diamondiferous and Barren Diatremes

(5) Lucasc H. ct al, 1989, 4th I.K.C., Kimberlitcs and Rclatcd Rocks, 2, 809-819, Gcol. Soc. Aust. publ., 12

(6) Sobolcv N.V. ct al, 1975, Gcologiya i Gcofizika, 16, 11, 7-24

(7) Gurncy J.J., 1989, 4th I.K.C., Kimberlites and Related Rocks, 2, 935-965, Gcol. Soc. Aust. publ., 14

(8) Nixon P.H. (cd), 1987, In: Mantle Xenoliths, John Wilcy Sons, Ncw York

(9) Gibbs G.V. and Smith J.V., 1965, Am. Mincral., 50, 2023-2039

(10) Novak G.A. and Gibbs G.V., 1971, Am. Mincral., 56, 791-825

(11) Hill R.J. ct al, 1979, Phys. Chem. Mincrals, 4, 317-339

(12) Cahay R. ct al, 1981, Bull. Mincral., 104, 193-200

(13) Prcudhommc J. and Tartc P., 1971, Spectrochcm. Acta, 27A, 845-851

(14) Whitc W.B. and De Angclis B.A., 1967, Spectrochem. Acta, 23A, 985-995

(15) Wang A., 1987, PhD. Thesis, LASIR. Lille, France, 152-179

(16) Wang W.Y., 1988, Master Thesis, CAGS, Bcijing, China, 39-52

(17) Guo L.H.ct al, 1990, In: Abstracts of The 15 th Gencral Mecting of IMA, 1, 427-429

(18) Guo L.H., 1988, Unpublished Report for CRA Exploration Pty Ltd.

(19) Guo L.H. ct al, 1990, In: Procecdings of.The 6th Conf. Mol. Spectro., 200-201
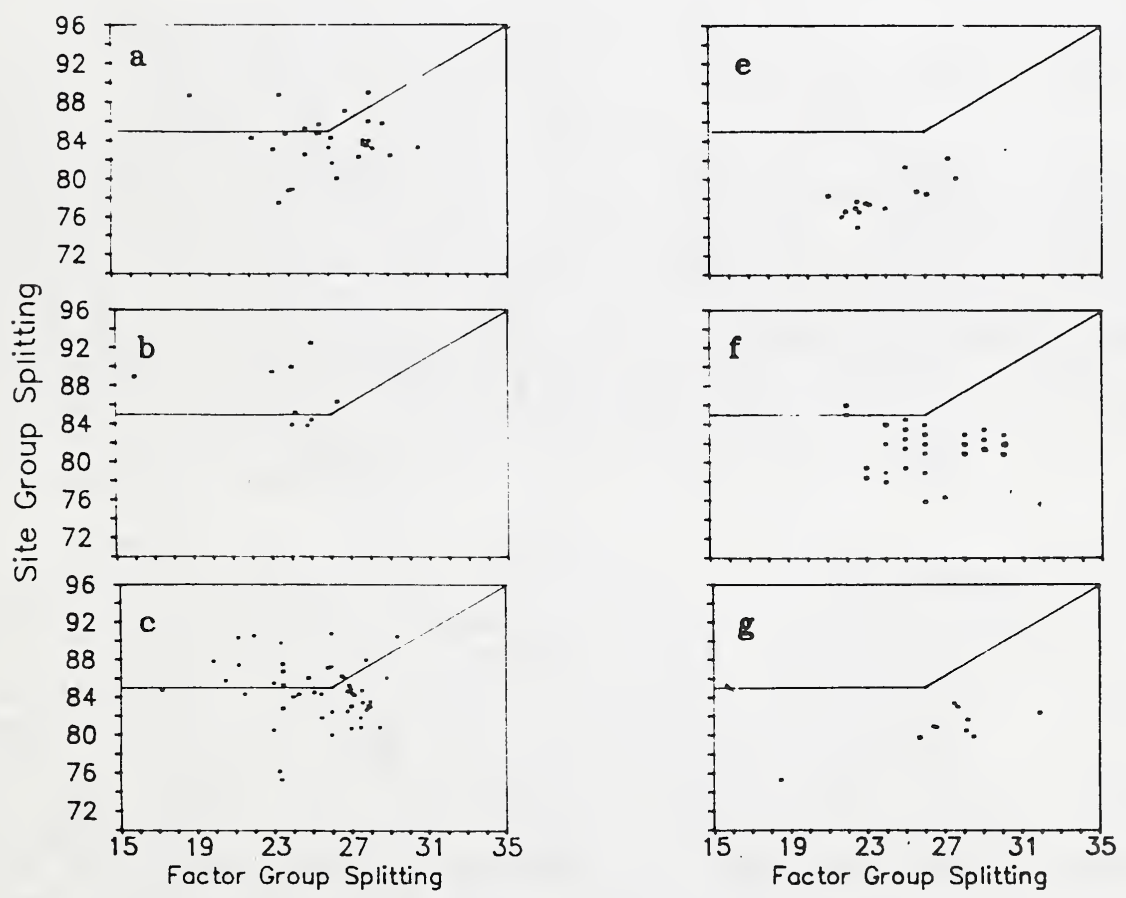

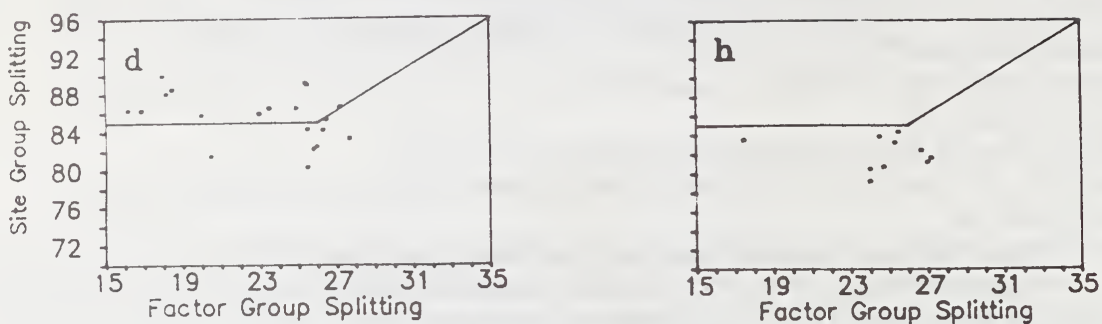

Fig. 2 Factor group splitting vs size gruop splitting of garnet Diamondiferous kimberlites (a-Liaoning 50, b-Liaoning 42,3-Shengli 1 and 4-Hongqi 1), Barren kimberlites ( (h-Jingshan)
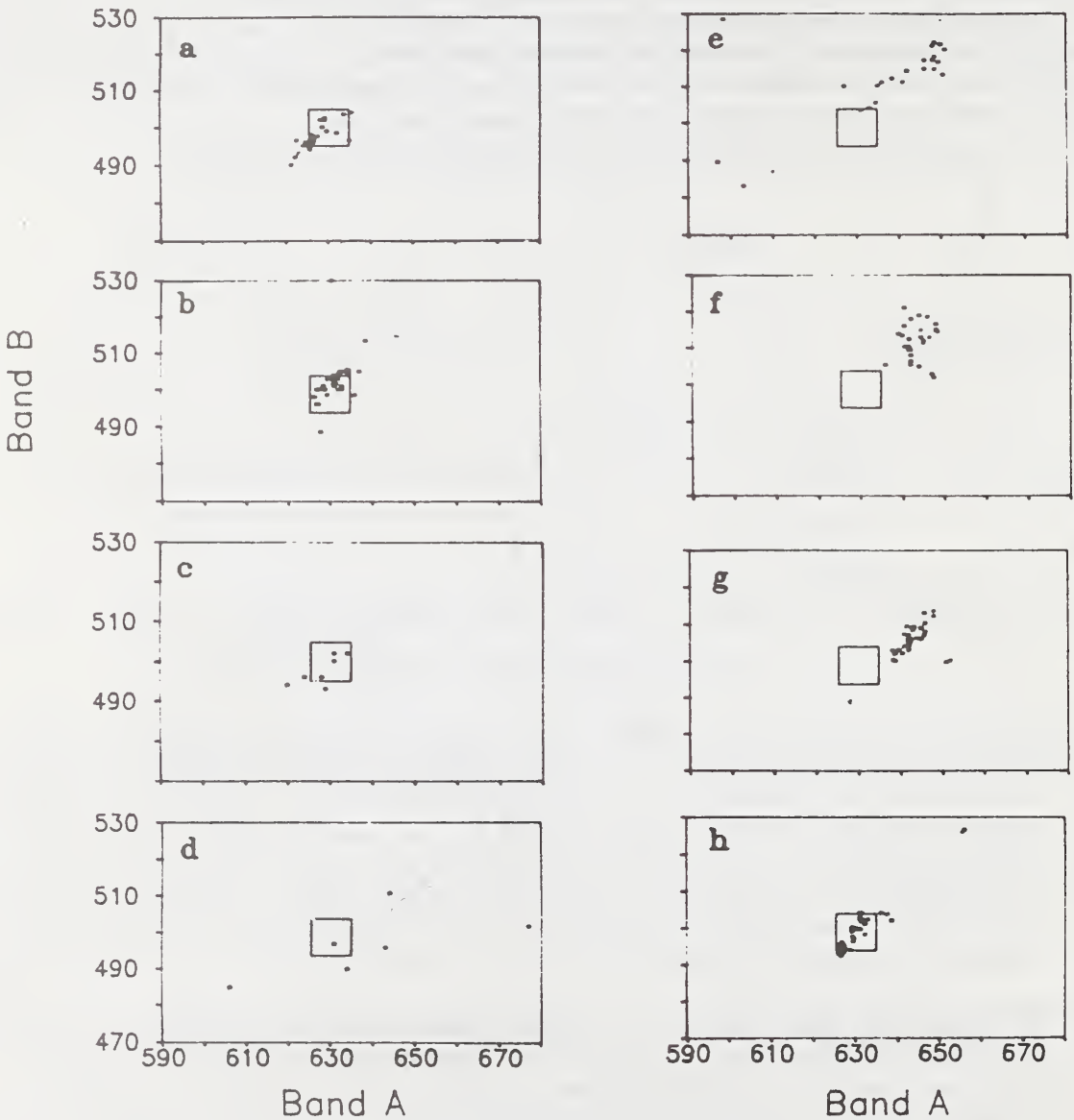

Fig. 3 Relationship of IR band A vs band B of chromite Diamondifcrous Kimberlites (a-Shengli 1, b-Liaoning 50, c-Koffiefontein) and lamproite (h-Ellendalc 4), Barren kimberlite (d-Rietfontein, e-Shexian), Related rocks (f-Anomaly 19 N.S.W., g-Narracoota Acid volcanics,W.A.) 